\title{
Fertility Cryopreservation
}

\author{
Francesca Ciani ${ }^{1}$, Natascia Cocchia ${ }^{2}$, Luigi Esposito ${ }^{3}$ and Luigi Avallone ${ }^{1}$ \\ ${ }^{1}$ Department of Biological Structures, Functions and Technology \\ ${ }^{2}$ Department of Veterinarian Clinical Sciences \\ ${ }^{3}$ Department of Animal Sciences and Inspection of Food of Animal Origin \\ University of Naples Federico II \\ Italy
}

\section{Introduction}

The cryobiology is the science of low temperature biology. Fertility cryopreservation is a vital branch of reproductive science and involves the preservation of gametes (sperm and oocytes), embryos, and reproductive tissues (ovarian and testicular tissues) for use in assisted reproduction techniques (ART). The cryopreservation of reproductive cells is the process of freezing, storage, and thawing of spermatozoa or oocytes. It involves an initial exposure to cryoprotectants, cooling to subzero temperature, storage, thawing, and finally, dilution and removal of the cryoprotectants, when used, with a return to a physiological environment that will allow subsequent development. Proper management of the osmotic pressure to avoid damage due to intracellular ice formation is crucial for successful freezing and thawing procedure.

Management of non-cryopreserved reproductive cells (i.e., spermatozoa or oocytes) and tissues (i.e., testicular tissue or ovarian tissue) is problematic due to difficulties in donorrecipient synchronization and the potential for transmission of infectious pathogens, which cumulatively limits widespread application of these techniques. Cryopreserved cells and tissues can endure storage for centuries with almost no change in functionality or genetic information, making this storage a method highly attractive. Cryopreservation procedures are established on the basis of cellular physical characteristics in order to maintain viability and limit membrane damage that may occur during exposure to such non-physiological conditions as sub-zero temperatures, ice format, ion and high solute concentrations. Afterwards, there is a pressing need for the development of optimum cryopreservation methods for reproductive cells and tissues from many species. There are two major techniques for cryopreservation: freeze-thaw processes and vitrification. The major difference between them is the total avoidance of ice formation in vitrification. However, the biotechnology of the reproduction, although widely implemented, has generated protocols currently used to cryopreserve bovine sperm or oocytes, for example, that are still suboptimal, and cannot readily be extrapolated to other species' gametes.

ART provide an ensemble of strategies for preserving fertility in patients and commercially valuable or endangered species. Nevertheless, it is very difficult to successfully cryopreserve. Currently, there is a growing interest to understand the 
underlying cryobiological fundamentals responsible for low survival rates in an effort to develop better cryopreservation.

The key factors that affect the life-span of spermatozoa are the combinations of storage temperature, cooling rate, chemical composition of the extender, cryoprotectant concentration, reactive oxygen species (ROS), seminal plasma composition and hygienic control. Sperm preservation protocols vary among animal species owing to their inherent particularities that change extenders used for refrigeration and freezing.

On the other hand, oocytes are available only in limited number as compared to spermatozoa, therefore, a cryopreservation protocol must allow a high rate of viability maintenance when they are employed in practical application in ART programs. One of the key factors that influence the freezing process is the ratio of surface area to volume. The oocytes require a longer time to reach osmotic balance with the cryoprotectant solution than the spermatozoa, due to their bigger volume. Then, during cooling of oocytes, various forms of cellular damage may occur, including cytoskeleton disorganization, chromosome and DNA abnormalities, spindle disintegration, plasma membrane disruption and premature cortical granule exocytosis with its related hardening of the zona pellucida.

Currently, there is an increasing research effort directed towards the utilization of cryopreserved testicular tissue containing abundant numbers of germ cells at various developmental stages. Advanced stage (i.e., spermatids, spermatozoa) germ cells can be successfully retrieved from cryopreserved testicular tissue following mechanical extraction or enzymatic digestion, and it is now possible to harvest these cells at earlier stages of development (i.e., spermatogonia) for further maturation in vivo.

The ovarian cortex contains many thousands of primordial follicles composed of early stage oocytes surrounded by a single layer of granulosa cells. These cells may be less sensitive to cryopreservation damage because they are small and without a zona pellucida. Therefore, animal gametes have been shown to survive storage at low temperatures, and recent results are very encouraging, although reproducible methods have yet to be obtained in many species.

\section{History}

The idea of cryopreserving human sperm dates back to 1776, when Lazaro Spallanzani, member of the italian clergy and scientist reported that sperm became motionless when cooled by snow. In 1866, Mantegazza was the first to suggest posthumous reproduction for soldiers about to die in combat by shipping their frozen sperm back home.

The technology behind reproductive cell and tissue cryopreservation has been derived from basic scientific principles, developed over the last 50 years. The use of theoretical techniques combined with experimental research has led to many exciting improvements and provided insight into optimal methods of cryopreservation. The fertility cryopreservation has been an ever increasing field since Polge et al., (1949), in United Kingdom, produced the first chicks from cryopreserved fowl sperm, in which, partly by error, a sample was frozen with additional glycerol. Afterwards, Bunge \& Sherman (1953) found that human spermatozoa treated with $10 \%$ glycerol and freezed with 'dry ice' survived in high precentage. Edwards et al. (1969) fertilized the first human egg in vitro. In the subsequent decades, assisted fertility 
clinics and commercial animal breeders have been using cryopreserved sperm successfully for artificial insemination. Although it had been shown that sperm could survive freezing and storage at low as $-196^{\circ} \mathrm{C}$, the functional ability of previously frozen sperm did not become apparent until the introduction of cryoprotectants. Sherman (1964) was the first to demonstrate the functional capacity of previously frozen sperm to fertilize an oocyte. The first successful human pregnancy as a result of frozen sperm was in 1969 and following this, the freezing of human sperm was largely done until the first sperm bank was opened in California in 1977. The birth of the first child to in vitro fertilization heralded the onset of a global expansion in the use of ART to treat infertile couples. This renewed the interest in cryobiological technology in an effort to preserve surplus embryo for future use (Kelly et al., 2003). Afterwards, methods of fertility recovery widened from sperm cryopreservation to oocytes and embryo cryopreservation.

\section{Cryobiology fundaments}

Cryopreservation holds tissues at temperature between -140 and $-200^{\circ} \mathrm{C}$, at this range no biological activity can occur, producing a state of "suspended animation" of tissue that can be maintained indefinitively (Fuller \& Paynter, 2004). Cryopreserved cells and tissues can endure storage for centuries with almost no change in functionality or genetic information, making this storage a method highly attractive. Cryopreservation is the process of cooling and warming, cryo-storage that harms cells or tissue (Mullen \& Critser, 2007; Barrett \& Woodruff, 2010).

Freezing is the separation of pure water as ice, which concentrates any solutes present in the remaining liquid phase. This raises the possibility of two sources of freezing injury, ice itself and the altered liquid phase. Water is everywhere in the cell, it is important for the functions of the macromolecules and other cell structures such as lipid membranes. It is the universal biocompatible solvent, but also possesses unique properties for stability of living cells. Low temperatures have defined effects on cell structure and function and it is the phase transition of water to ice that is the most profound challenge for survival (Fuller \& Painter, 2004). Some effects of cooling are frankly harmful: for example, cooling switches off the Napump, which is responsible for the regulation of cell volume, and as a result cooled cells swell (Leaf, 1959); membrane lipids undergo phase changes which may in themselves be harmful, and which also have dramatic effects on the reaction rates of membrane-bound enzymes (Lyons, 1972); poorly soluble materials may precipitate, and dissociation constants change, resulting in changes in the composition and $\mathrm{pH}$ of solutions (van den Berg, 1959; van den Berg and Rose, 1959); some cells are damaged or even killed by a reduction in temperature per se, especially if cooling is rapid, a phenomenon known as thermal shock (Lovelock, 1955).

An implicit assumption is that the conditions leading to the formation of large ice crystals inside the cell is lethal (Mazur, 1977), then to preserve structurally intact living cells and tissue, the techniques of cryopreservation focus attention on the mechanisms of damage and protection in living cells and tissues at low temperatures in attempts to preserve the viability of tissues (Muldrew \& McGann, 1990). Several approaches are being taken to understand and avoid potential damaging conditions during cooling by reducing the total amount of ice formed (Farrant et al., 1977), or by preventing the formation of ice (Mazur, 1963). 
The formation of ice in the environment of the cell induces changes to which the cell must respond. The morphology of ice crystals formed during freezing depends on many factors, including the composition of solution, the cooling rate, and the temperature. When a cell suspension is cooled below its freezing point, water is removed from the isotonic solution in the form of ice, increasing the concentration of solutes (e.g., salt), which remain in the unfrozen fraction and hence increasing the osmotic pressure of the remaining unfrozen solution which not only helps to reduce ice formation inside the cell but also severely dehydrates cells and can cause cell damage and death. The isotonic salt solution $(0.15 \mathrm{M})$ is cooled at $-0.56^{\circ} \mathrm{C}$. As the cooling is continued, and further ice separates, the salt, in the remaining liquid, is more concentrated. The remaining solution is progressively diminished in volume and increased in strength until at $-21.1^{\circ} \mathrm{C}$ the saline has reached a concentration of $5.3 \mathrm{M}$; at this temperature, eutetic point, the remaining solution solidifies. Therefore, when cells are suspended in isotonic saline that is frozen, they are subjected to a 32 -fold increase in sodium chloride concentration. In the mixed solute systems that occur in practice, similar changes in osmolality occur, but in addition there are changes in composition brought about by differing solubility characteristics of the various solutes (Pegg, 1976; 2007). The dynamics of cell volume change are important in relation to possible membrane damage by mechanical means such as plasma membrane stretching and even rupture (Leibo et al., 1978; Mazur \& Schneider, 1986).

The formation of ice is normally entirely extracellular. There are several reasons for this. In the first place, when heat is removed by conduction from the external surface of the specimen, the coldest point will always be in the extracellular fluid. Secondly, the extracellular fluid forms one large compartment, whereas the intracellular space consists of very many small compartments: the probability of ice nucleation occurring in any given compartment is directly related to its size, and this makes it inevitable that nucleation will occur in the extracellular fluid before a significant number of cells have frozen internally. Once ice has started to form, it will propagate throughout that compartment until equilibrium is reached. Hence, even if a few cells should freeze internally before extracellular freezing starts, once extracellular ice has formed it will continue to grow in that space, and since cell membranes are impermeable to the main solutes present, water will be withdrawn from the cells by the increased external osmolality. Hence the cells will shrink, and so long as cooling is slow enough to allow water to leave the cells to maintain equilibrium, no further intracellular freezing will occur. Thus, it is important to understand how cooling can be used to produce stable conditions that preserve life.

Although many cells and tissues can be successfully cryopreserved, without intracellular ice formation, and can be stored in liquid nitrogen indefinitely, there could be the risk of ice formation during the thawing process, if conducted improperly. If samples are thawing slowly, ice crystals can form and/or grow causing more damage; however, if samples are thawed rapidly enough, there is little time for ice nucleation and growth to occur (Fabbri, 2006; Fabbri et al., 2006).

The phenomenon of recrystallization in frozen samples occurs as smaller ice crystals with higher surface energy dissolve and larger crystals grow; the rate of recrystallization increases with increasing temperature (Mazur \& Schmidt, 1968). Recrystallization of both intracellular and extracellular ice occurs during warming although the total amount of ice decreases as the temperature increases. It has been suggested that cells cooled under 
conditions resulting in little intracellular ice formation may be recovered undamaged if the warming rate is rapid, but would be irreparably damaged by the recrystallization of the intracellular ice on slow warming. This suggests that membrane damage caused by the osmotic pressure gradient may be resealed if the warming conditions prevent the recrystallization of ice crystals traversing the membrane (Mazur et al., 1972; McGann \& Farrant, 1976). A similar resealing repair mechanism for freeze-thaw damaged cells was proposed by Law et al. (1980) which could also explain the $6 \%$ of cells that retained their barrier properties after forming intracellular ice. After thawing, there is further risk of damage during the course of removing cryoprotectants. If cells are immediately put into a significantly lower concentration of cryoprotectant, water will rapidly move into the cell and the cells can swell and burst. Therefore, it is usually advised that a series of decreasing concentrations of cryoprotectant is used to slowly remove the cryoprotectants and gently rehydrate cells. As an alternative, it can also be very effective to use a non-penetrating cryoprotectant such as sucrose to reduce osmotic shock during the step-down process (Shaw, 2000).

\section{Cryopreservation methods}

Two are the most utilized methods for gamete cryopreservation: slow freezing and vitrification. Slow freezing uses low concentrations of cryoprotectants which are associated with chemical toxicity and osmotic shock. Vitrification is a rapid method that decreases cold shock, without the risks of solution effects or crystallization, and uses high cooling rates in combination with a high concentration of cryoprotectant (Arav et al., 2002).

\subsection{Slow freezing}

Slow freezing is a conventional cryopreservation process in which a relatively low concentratiton of cryoprotectant is used $(1.5 \mathrm{M})$, it shows little toxicity to cells or tissue and requires expensive equipment. As the cryoprotectant is added to cells, it results in initial cellular dehydration followed by a return to isotonic volume with the permeation of cryoprotctant and water. Generally, cells are cooled slowly using a controlled rate freezing machine, which allows samples to be cooled at various rates; ovarian tissue is generally cryopreserved at $2^{\circ} \mathrm{C} / \mathrm{min}$ prior to ice seeding and $0.3^{\circ} \mathrm{C} / \mathrm{min}$ after crystallization to ensure the tissue is dehydrated before intracellular ice formation occurs. Optimal rates to minimize intracellular rates formation vary among cells and tissue types (Fuller \& Painter, 2007).

It is generally believed that cell injury at low cooling rates is principally due to the concentration of both intracellular and extracellular electrolytes and that cryoprotectants act by reducing this build-up. Experimental data support this explanation, in fact the extent of damage to human red blood cells during freezing in solutions of sodium chloride/glycerol/water can be quantitatively accounted for by the increase in solute concentration. Furthermore, a given degree of damage occurs at lower concentrations of solute in the presence of higher concentrations of glycerol; it appears that glycerol contributes as element of damage itself (Barbas \& Mascarenhas, 2009).

\subsection{Vitrification}

Whereas in conventional cryopreservation the concentration of the cryoprotectant is low and the cooling rate is very slow to avoid ice crystallization, vitrification is an ultrarapid 
cooling technique that requires a high concentration of cryoprotectant. In 1985, vitrification was first reported with mouse embryos (Rall \& Fahy, 1985) and was then further developed in animal reproduction (Ali \& Shelton, 1993). In 1999 the first successful pregnancies and deliveries after vitrification of human oocytes were reported (Kuleshova et al., 1999). Since then, scientific interest on vitrification has risen significantly (Liebermann et al., 2002; 2003). The physical definition of vitrification is the solidification of a solution at low temperature, not by ice crystallization but by extreme elevation in viscosity during cooling, such that the cells or the tissues are placed into the cryoprotectant and then plunged directly into liquid nitrogen. Water is largely replaced by the cryoprotectant. The cooling rate achieved is between 15.000 to $30.000^{\circ} \mathrm{C} / \mathrm{min}$, and water is transformed directly from the liquid phase to a glassy, vitrified state. With this method no ice crystals form that can damage the cells or the tissues. This approach is attractive from a technical standpoint; unfortunately, cyroprotectant solutions are toxic to cells at very high concentrations. Solute toxicity is a major drawback of using vitrification for preservation, even with high cooling rates. To reduce toxicity, concentrations of cryoprotectants can be lowered as long as cooling is fast enough to preclude ice formation (Herrero et al., 2011).

\section{Cryoprotectants}

Intracellular freezing is generally lethal but can be avoided by sufficiently slow cooling, and under usual conditions solute damage dominates. However, extracellular ice plays a major role in cells and tissues. Cryoprotectants are defined functionally as any compound that increases cell survivability when used in a cryopreservation method and act primarily by reducing the amount of ice that is formed at any given subzero temperature. If sufficient cryoprotectant could be introduced, freezing would be avoided altogether and a glassy or vitreous state could be produced, but osmotic and toxic damage caused by the high concentrations of cryoprotectant that are required then become critical problems. The transport of cryoprotectants into and out of cells and tissues is sufficiently well understood to make optimization by calculation a practical possibility but direct experiment remains crucial to the development of other aspects of the cryopreservation process.

Cryoprotectants are included in cryopreservation medium to reduce the physical and chemical stresses derived from cooling, freezing and thawing of sperm cells (Gao et al., 1997; Purdy, 2006). Cryoprotectants are classified as either penetrating or non penetrating. Penetrating cryoprotectants (glycerol, dimethyl sulfoxide, ethylene glycol, propylene glycol) cause membrane lipid and protein rearrangement, resulting in increased membrane fluidity, greater dehydration at lower temperatures, reduced intracellular ice formation, and increased survival to cryopreservation (Holt, 2000). Additionally, penetrating cryoprotectants are solvents that dissolve sugars and salts in the cryopreservation medium (Purdy, 2006). A non penetrating cryoprotectant (egg yolk, nonfat skimmed milk, trehalose, aminoacids, dextrans, sucrose) doesn't cross plasma membrane and only acts extracellularly (Aisen et al. 2000). Therefore, non penetrating cryoprotectant may alter the plasma membrane, or act as a solute, lowering the freezing temperature of the medium and decreasing the extracellular ice formation (Amann, 1999; Kundu et al. 2002).

The historic discovery of the cryoprotective effect of glycerol was made in 1948 when Polge et al. (1949) found that fowl spermatozoa had been cooled to $-76^{\circ} \mathrm{C}$ in $1.1 \mathrm{M}$ glycerol recovered with little damage after thawing. Many commonly used cryoprotective agents 
penetrate cell membranes actually produces some problems and is certainly not a necessary property for cryoprotection. Penetrating cryoprotective agents like glycerol and dimethylsulphoxide (DMSO) permeate a good deal more slowly than water and consequently they all produce osmotic transients, the severity and duration of which vary with the compound and the cell in question. In general, osmotic disturbances have more severe effects during thawing and resuspension of the cells in cryoprotectant-free medium (when the solute is leaving the cells) than during initial equilibration and cooling (when it is entering the cells). This is due to the greater sensitivity of cells to swelling than to shrinkage. It is certainly very important to minimize osmotic disturbances during thawing and subsequent manipulations since they can contribute very significantly to the damage suffered by stored cells and tissues.

The most used cryoprotectant for sperm is glycerol. Similar to nonpermeating cryoprotectants, glycerol exerts an extracellular effect by osmotic stimulation of cell dehydration, thus decreasing the volume of intracellular water available for freezing. An intracellular effect of glycerol, exerted through its ability to permeate the cell membrane, is a decrease of intracellular osmotic stress effect of dehydration. This occurs by replacing intracellular water necessary for the maintenance of cellular volume, interaction with ions and macromolecules, and depressing the freezing point of water. Permeating cryoprotectants, depending on the concentration used, are toxic and can induce membrane damage and decrease sperm motility. Important cellular features for determining the most appropriate freezing rates as well as types and concentrations of cryoprotectant used are surface to volume ratio, membrane permeability to water, and cryoprotectants (and the corresponding activation temperatures) and membrane liability to physical stress. Spermatozoa from different species require different protocols for successful cryopreservation because of inherited particularities in cell shape, cell volume, organelles size, and composition (Medeiros et al., 2002).

Currently, three are the widely used permeating cryoprotectants in fertility cryopreservation: dimethyl sulfoxide (DMSO), ethylene glycol (EG), and propylene glycol (PG). These cryoprotectants have similar properties: solubility in water at low temperatures, cell permeability, and relatively low toxicity. However, each of these CPAs also has different degrees of membrane permeability, as has been shown with mammalian oocytes.

The transport of cryoprotectants into and out of cells and tissues is sufficiently well understood to make optimization by calculation a practical possibility but direct experiment remains crucial to the development of other aspects of the cryopreservation process.

\section{Germplasm cryopreservation}

\subsection{Why cryopreserve genetic material?}

Assisted reproductive technologies (ART) provide an ensemble of strategies for preserving fertility in patients and commercially valuable or endangered species. Cryopreservation is a way of preserving germplasm that have applications in agriculture, aquaculture, biotechnology and conservation of threatened species (Holt, 1997; Andrabi \& Maxwell, 2007).

Fertility cryopreservation is an emerging field that encompasses a variety of fertility therapies for patients anticipating medical treatment that could affect future reproductive 
outcomes. Although most frequently associated with cancer treatment, fertility preservation has also been used for medical conditions like lupus, glomerulonephritis, and myelodysplasia, as well as in adolescent females with conditions known to be associated with premature ovarian failure (Jensen et al., 2011).

Current indications for sperm storage are quite broad and include every case and circumstance in which a future damage to the male reproductive system is suspected. It is known that sperm cryopreservation mainly affects its motility (Donnelly et al., 2001). The indications for spermcryobanking have been greatly expanded since oocytes can be fertilized even by one viable spermatozoon through intracytoplasmic sperm injection (ICSI) (Palermo et al., 1992). Although intrauterine insemination with thawed sperm is less successful that with fresh sperm (Sherman, 1973), ICSI with thawed sperm is successful as long as viable spermatozoa are injected (Kuczynski et al., 2001). This procedure has enabled men who have few surviving seminal or even testicular spermatozoa to fertilize their partner's oocytes. ICSI provides a realistic chance to achieve pregnancies and births when the sperm quantity and quality is extremely low, and in cases in which the sperm source is not renewable.

Concerning threatened species, cryopreservation of genetic material is used to the genetic management programmes of those species and genetic resource banking (Holt, 1997). Semen banks are currently more developed for rare domestic breeds (cattle, sheep, goats and pigs) than for non-domestic species, but the concept of using them to facilitate the management and conservation of endangered species is being promoted extensively (Roth et al., 1997). In order to maximize genetic diversity, a rare animal from the family bovidae could be saved with 1000 sperm doses collected from 25 different males (Comizzoli et al., 2000).

Nowadays, semen cryopreservation has other biotechnological applications. It can also be used to solve problems of preservation of semen and DNA from endangered species and, therefore, conservation of biodiversity. Cryopreservation of gametes is an important tool in assisted reproduction programmes; long-term storage of oocytes or spermatozoa is necessary when in vitro fertilization (IVF) or artificial insemination is to be performed at a future date or when geographical or temporal distance between donors result in non-simultaneous availability of male and female gametes, conservation by cryopreservation is the only option (Luvoni \& Pellizzari, 2000). Cryopreservation of spermatozoa, oocytes, and embryo offer a potential tool for rescuing genetic material from alive or dead males or females of endangered populations, both if they are (Ciani et al., 2008; Cocchia et al., 2009; 2010).

Cryopreservation of testicular tissue would benefit at least two groups of patients: prepubertal boys who are undergoing chemotherapy or radiotherapy and infertile men who are undergoing testicular biopsy. In spite of attempts to protect seminiferous epithelium by hormone treatments (Meistrich et al., 1996; Thomson et al., 2002), prepubertal boys often lose their sperm production during cancer treatment. Especially in connection with bone marrow transplantation, the destruction of spermatogonia is often inevitable, and also the Leydig cells probably undergo damage (Siimes \& Rautonen, 1990). In postpubertal boys and men, cryopreservation of semen is clinically well established and widely used, but also in them, restoration of natural fertility after cancer treatment would be a great benefit (Song et al., 2010).

Management of non-cryopreserved reproductive cells (i.e., spermatozoa or oocytes) and tissues (i.e., testicular tissue or ovarian tissue) is problematic due to difficulties in donor- 
recipient synchronization and the potential for transmission of infectious pathogens, which cumulatively limits widespread application of these techniques (Woods et al., 2004). Paralleling the introduction of cryobiology to assisted reproduction has been the realization of a number of moral and ethical issues to gamete and/or embryo storage (Kelly et al., 2003).

\subsection{Sperm cryopreservation}

The most broadly practiced mammalian spermatozoa cryopreservation methods consist of a series of non-physiological steps that involve hypertonic cryoprotectant addition, cooling, warming, and cryoprotectant removal. Several studies have focused on the fundamental biophysical conditions that determine optimal cryoprotectant addition and removal, and cooling and warming rates (Morris et al., 1999). With this type of approach, it becomes theoretically possible to calculate the minimal number of cryoprotectanct. Sperm cryopreservation has been most successfully associated with human and bovine reproductive technologies. The most successful cryopreservation methods for spermatozoa from these species use slow initial cooling rates $\left(1-5^{\circ} \mathrm{C} / \mathrm{min}\right)$ starting from room temperature to a seeding temperature, followed by faster cooling rates after initial ice formation $\left(100-200^{\circ} \mathrm{C} / \mathrm{min}\right)$ in the presence of glycerol buffered with egg yolk-citrate medium.

Mammalian sperm are very sensitive to cooling from body temperature to near the freezing point of water. Damage to sperm, known as cold shock, is observed as an irreversible loss of motility upon rewarming. Cold shock effects on other cellular functions, such as loss of selectivity in membrane permeability, can be observed as intracellular staining with dyes that are not permeable to the intact plasma membrane. Ultrastructurally, cold shock is manifested most clearly by a disruption of the acrosomal membranes.

Membrane permeability is increased after cooling and this may be a consequence of increased membrane leakiness of specific protein channels. Calcium regulation is affected by cooling and this has severe consequences in cell function, inclusively cell death. The uptake of calcium during cooling influences capacitation changes and fusion events between plasma membrane and acrosomal membrane. Sperm membrane is a structure that undergoes reorganization during capacitation, and cryopreservation results in sperm being more reactive to their environment (Bailey et al., 2000). Cold shock reduces membrane permeability to water and solutes and injures acrosomal membranes (Purdy, 2006). The main changes that occurs during freezing are mainly ultrastructural, biochemical and functional, which impairs sperm transport and survival in the female reproductive tract and reduces fertility in domestic species (Salamon \& Maxwell, 2006). The ultra structural damage is greater in ram than bull spermatozoa. Greater damages have been detected in plasma and acrosome membranes, mitochondrial sheath and axoneme (Salamon \& Maxwell, 2006; Barbas \& Mascarenhas, 2009).

There are only few studies dealing with sperm vitrification. Classical vitrification technique with high concentration of permeable cryoprotectants (30 to $50 \%$ ) cannot be performed to cryopreserve human spermatozoa because of the lethal effect of osmotic shock. This is why vitrification had been performed mostly with oocytes and embryos. An alternative could be to use very rapid cooling and warming rates on a very small sample size. It has been shown that vitrification of human spermatozoa using cryoloops without cryoprotectants is possible Nawroth et al., 2005). Furthermore, why can vitrification be successful in the absence of 
cryoprotectants? Probably it depends on the size and the more stability of human spermatozoa respect to other mammals (boar, bull, ram, rabbit, cat, dog, and horse). Furthermore, the amount of osmotically inactive water is higher in spermatozoa, and is bound to several macromolecular structures such as DNA, histones, hyaluronidase, etc. (Thurston et al., 2002). Therefore, the amount of high molecular weight components can be 6-16 times higher than in embryos, resulting in enhanced viscosity and glass transition temperature The DNA integrity of vitrified sperm is comparable with that of slowly frozen/thawed spermatozoa. Such findings suggest that a wide range of cooling rates for spermatozoa can be acceptable (Isachenko et al., 2003; 2004a; 2004b; Nawroth et al., 2005).

Cryopreservation of testicular tissue is offered in some centres but is still considered experimental; potential future uses include in vitro maturation of spermatogonia into spermatocytes or germ-cell transplant into native testicular tissue.

\section{Female germplasm cryopreservation}

\subsection{Introduction}

During the course of the last 55 years, the science of reproductive biology, namely in vitro fertilization (IVF), has coincided with the ability to preserve embryos and oocytes (Fuller \& Paynter, 2004). Currently, embryo and oocyte cryopreservation is the sole approved technology for human female patients wanting to preserve genetic material for future use.

Preservation of female genetics can be done through the preservation of germplasm (oocytes and embryos). It can also be done by preservation of ovarian tissue or entire ovary for transplantation, followed by oocyte harvesting or natural fertilization.

For most of the species on Earth, with current knowledge in cryopreservation, probably only male gametes can be preserved, whereas oocytes or embryos at any stage of development cannot. The culprits are in the vast differences in size, composition, and associated structures. As such, the issue of intracellular ice formation becomes a major concern, even at relatively slow cooling rates.

Embryo cryopreservation has been a proven method to preserve fertility. The first report on successful embryo cryopreservation was published in Whittingham (1977), Whittingham et al. (1972), Wilmut (1972) and Wilmut \& Rowson (1973), more than two decades after Polge et al. (1949), that reported their success in freezing spermatozoa. The modification of cooling rate that came a few years later (Willadsen et al,. 1976; 1978) resulted in a basic protocol that is still in large use today. Thus, cryobanking of embryos can help in establishing founder populations with the aim of eventual reintroduction into the wild (Ptak et al,. 2002). However, evolution made each species unique in many aspects, one of which is the development of highly specialized reproductive adaptation, a specialization that is part of the definition of a species. While thousands and thousands of offspring were born following the transfer of frozen-thawed embryos in humans, cattle, sheep, and mice, success is very limited in many other, even closely, related species (Abe et al., 2011; Aller et al., 2002).

To date, the number of species in which embryo cryopreservation has been reported stands only at about 40 including humans and domestic and laboratory animals. In wild animals, especially with endangered species, this is often almost impossible, and the opportunity to collect oocytes or embryos is very rare. To overcome this limitation, 
researchers find imperative to use laboratory, farm, or companion animals as models during the process of developing of the necessary reproductive techniques associated with embryo cryopreservation. In some instances, appropriate model species were found. For example, studies on the domestic cat helped to develop various technologies, which were later applied to nondomestic cats (Dresser et al. 1988; Pope et al., 1984; Pope, 2000; Cocchia et al., 2010) or cattle served as a model for other ungulates (Loskutoff et al., 1995). Unfortunately, for many species (e.g. elephant, rhinoceros), no suitable model can be located, and studies should be conducted with the limited available resources with relying on the already available knowledge from research on other species (Bilton \& Moore, 1976; Breed et al., 1994).

Cryopreservation of embryos in the few mammalian species in which it was attempted shows some, though often very limited, success. When considered from conservation standpoint, embryo freezing has the advantage of preserving the entire genetic complement of both parents, but it is not always possible to obtain embryos for the female valuable genetic material preservation. In many situations, then, oocyte and ovarian tissue cryopreservation represent an attractive potential means of preserving female germ cells for subsequent use in assisted reproduction (Vajta \& Nagy, 2006; Abir et al., 2006; Whittingham \& Adams, 1974).

In Human Chemotherapy and/or radiotherapy can induce premature ovarian failure in most of female cancer patients. Some patients may be too sick or too young to undergo fertility treatments or have hormone sensitive cancers that preclude standard approaches. As current cancer treatments improve, the survival rate of young female cancer patients has steadily increased. However, ionizing radiation and most of alkylating agents (e.g., busulfan, carboplatin, chlorambucil, cisplatin, cyclophosphamide, dacarbazine, ifosfamide, thiotepa) that used for gonadotoxic chemotherapy regimens can often induce premature ovarian failure, rendering the patient infertile. In addition, bone marrow transplantation, which is used in the treatment of cancerous and noncancerous hematologic diseases, also results in ovarian failure because heavy chemotherapy and radiotherapy is utilized to destroy the pre-existing bone marrow. Also, in nearly all cancers, with the possible exception of breast cancer, chemotherapy is initiated soon after diagnosis. Because preparation and stimulation for oocyte retrieval usually requires 2 to 3 weeks or longer, it is generally not feasible to freeze embryos from an adult female cancer patient for potential future use. Even in breast cancer patients, most would not be candidates for oocyte or embryo freezing due to concerns that high estrogen levels might have detrimental effects on the primary tumor. Additionally, not all patients have partners with whom they can create embryos for cryopreservation.

Therefore, most female cancer patients of reproductive age do not have the option of utilizing established assisted reproductive technologies to safeguard their fertility so far.

For women facing upcoming cancer therapies, cryopreservation of ovarian tissue and oocytes is a technology that holds promise for banking reproductive potential for the future.

Also, oocytes freezing offers future "social choice" in single woman, for ethical or religious problems or for governmental regulation. Non-human primates serve as research models for humans in a wide variety of fields, things work the other way around when it comes to female germplasm cryopreservation (Almondin et al., 2010; Cranfield et al., 1992). Industry 
needs pushed frozen-thawed ET in the cattle industry to commercial levels (Abe \& Hoshi, 2003; Armstrong et al., 1995). According to a recent report by the International ET Society, over 300000 frozen-thawed bovine embryos were transferred in 2008 worldwide. In this species, oocyte cryopreservation is very successful, and it has led to develop other correlates methods, such as superovulation techniques, and ovum pick up and In Vitro Embryo Production (IVEP) with no surgical methods.

The domestic buffalo (Bubalus bubalis) is a multipurpose livestock species in many countries of the world, particularly in South Asia, the Mediterranean region of Europe and South America, and is an indispensable source of employment to the marginal farmers and landless labourers. Recent advances in reproductive techniques, including superovulation, ovum pick-up and cryopreservation of oocytes offer numerous possibilities for the wider exploitation and dissemination of superior buffalo genotypes. Although the horse was probably the first animal to experience and benefit from artificial insemination, it trailed the field somewhat with regard to the application of embryo transfer and other oocyte and embryo-related modern breeding technologies.

In wild animals, especially with endangered species, it is very rare to collected the embryo but the collection of oocytes or ovary is possible, eventually also post mortem. For example the cryopreservation of female germoplasm is an important tool in assisted reproduction programs of feline species. Gamete cryopreservation represents an important tool for the development of efficient ART, and oocyte cryopreservation could facilitate the preservation of genetic resources in domestic and wild animals. It has been demonstrated that the domestic cat oocytes can serve as a successful recipient of nuclear transfer from related nondomestic cats (Cocchia et al., 2010).

Maintenance of biodiversity has intrinsic value for the genetic preservation of valuable domestic cat breeds and an extrinsic value for conservation management of taxonomically related non-domestic feline species (Luvoni, 2006). These observations are valid in different wild species as carnivore or ungulate. However, while live offspring have been produced using cryopreserved oocytes in a number of species: man (Chen, 1986); mouse, cattle, horse (Maclellan et al., 2002). The oocytes collection before cryopreservation or in vitro embryo production can be performed at different stage. The oocytes at a very early stage of maturation or immature (GV stage) can be collected from birth or sexually immature animals from ovary or ovarian tissue collected by surgery or post mortem. The mature oocytes (MII stage) can be collected from woman and mammalian after puberty by hormonal stimulation and non-surgery ovum pick-up.

To be fertilized, an oocyte needs to reach the metaphase II (MII) stage of maturation, or otherwise the probability of fertilization is very low (Luvoni \& Pellizzari 2000). Thus, an in vitro maturation (IVM) procedure should be in hand to handle immature oocytes, and this process is currently developed for only a handful of species and even for these success is often fairly limited (Krisher, 2004). Furthermore, collection of immature oocytes following chemical stimulation disrupts the natural maturation process and thus compromises the quality of oocytes even if they were later matured in vitro (Moor et al., 1998; Takagi et al., 2001). During oocyte maturation and follicular growth, oocytes accumulate large quantities of mRNA and proteins needed for continuation of meiosis, fertilization, and embryonic development (Krisher, 2004). In the absence of the entire supporting system during IVC, production of some needed components is hampered resulting in suboptimal oocytes 
(Krisher, 2004). Despite numerous studies on the issue, to date, no morphological or other method is able to accurately predict which oocytes have optimal developmental potential (Coticchio et al. 2004). Even so, it is clear that oocyte quality is a major determining factor in the success of IVF, early embryonic survival, establishment and maintenance of pregnancy, fetal development, and even adult disease (Coticchio et al. 2004, Krisher 2004; Wolf et al., 1989). Once all these hurdles have been overcome and keeping in mind the importance of oocyte quality, the next major hurdle to overcome is oocyte cryopreservation (Allen, 2010).

\subsection{Oocyte cryopreservation}

\subsubsection{Factors affecting oocyte freezing and resolution}

Oocytes are very different from sperm or embryos with respect to cryopreservation. The volume of the mammalian oocyte is in the range of three to four orders of magnitude larger than that of the spermatozoa, thus substantially decreasing the surface-to-volume ratio and making them very sensitive to chilling and highly susceptible to intracellular ice formation (Ruffing et al., 1993, Arav et al., 1996).

This problem becomes even more pronounced in non-mammalian vertebrates (fish, birds, amphibians, and reptiles) whose oocytes are considerably larger than those of mammals (Guenther et al., 2006). Oocytes of amphibians, for example, are 20-25 times larger than human oocytes. Several parameters have been taken into account in oocyte cryopreservation: cell characteristics, permeability to the cryoprotectants, toxicity, temperature and time of exposure to the cryoprotectants. Chilling injury is the main obstacle to successful oocyte cryopreservation. It has been reported that chilling injury affects the membrane, the microtubule, the cytoskeletal organization and the zona pellucida. Chromosome abnormalities also were observed after cryopreservation of human and mouse oocytes. Most striking sample is the effects of freezing on the second meiotic spindle where microtubules are disrupted or disassembled because of tubulin depolimerization.

Several approaches have been used to overcome the damage caused by chilling injury. Significant improvements have been obtained with rapid cooling throughout the transition phase, or by the addition of substance known to stabilize the plasma membrane against the thermal effect of oocytes: such as proteins (linoleic acid-albumin), sugar (sucrose or trehalose) anti-oxidant (Butylated Hydroxytoluene). In addition, supplementation of choline and higher sucrose concentration in the freezing solution can promote the retention of an intact chromosome segregation apparatus comparable in incidence to freshly collected oocytes (Willadsen et al., 1974).

\subsubsection{Effect of meiotic stage}

The meiotic stage seems to influence the survival of oocytes after freezing. Differing sensitivity to the cooling procedures for the oocyte cryopreservation has been related to the cell cycle stage during meiosis. The metaphase-II (MII) oocyte is extremely fragile due to its large size, water content, and chromosomal arrangement. In the mature oocyte, the metaphase chromosomes are lined up by the meiotic spindle along the equatorial plate.

Increases in chromosomal aberrations in matured oocytes were observed upon cooling and cryopreservation due to the alteration to the meiotic spindle. MII oocytes are susceptible to 
cryopreservation damage because of disruption of the metaphase spindle microtubule integrity during slow cooling, which may result in aneuploidy after fertilization of thawed oocytes. The plasma membrane of oocytes at the MII stage has a low permeability coefficient, thus making the movement of CPs and water slower (Ruffing et al., 1993). They are surrounded by zona pellucida, which acts as an additional barrier to movement of water and CPs into and out of the oocyte. As a result of the freeze-thaw process, premature cortical granule exocytosis may take place, leading to zona pellucida hardening and making sperm penetration and fertilization impossible (Mavrides \& Morroll, 2005), a process that can be overcome by the use of ICSI or subzonal sperm insertion. Oocytes also have high cytoplasmic lipid content that increases chilling sensitivity (Ruffing et al., 1993). They have less submembranous actin microtubules making their membrane less robust. Cryopreservation can cause cytoskeleton disorganization, and chromosome and DNA abnormalities (Luvoni, 2006). The meiotic spindle, which has been formed by the MII stage, is very sensitive to chilling and may be compromised as well (Ciotti et al., 2009). It does, however, tend to recover to some extent after thawing or warming and IVC, recovery that is faster following vitrification than following slow freezing (Ciotti et al., 2009). Oocytes are also more susceptible to damaging effects of reactive oxygen species (Gupta et al., 2010). Despite many advances in the field of cryopreservation, specifically with regards to oocytes (ovulated, mature or immature), their cryopreservation is still not considered an established procedure and thus its current label as experimental technique (Noyes et al., 2010).

An alternative to cryopreservation of mature oocyte is to freeze oocyte when they have reached full size and become meiotically competent, but before they resume maturation and proceed to MII. It has been showed that oocytes frozen at the germinal vesicle (GV) stage survive better than those frozen at the metaphase-II stage (Luvoni \& Pellizzari, 2000). Additionally, oocytes frozen at the GV stage have lower rates of abnormalities in the resulting meiotic spindle than oocytes frozen at the MII stage. At this stage the oocyte does not present a chilling-sensitive microtubular or meiotic spindle. Several other reports, however, paradoxically showed that the immature oocytes are more sensitive to freezing than mature oocytes, probably due to lower cell membrane stability and a particular cytoskeletal formation. This sensitivity to cryopreservation also seems to be due to the damage or interruption of cumulus cell projections, which may control the intercellular communication between cumulus cells and oocytes during maturation. Even though GV oocytes have a superior thaw survival rate and a lower incidence of meiotic spindle damage, the continued inefficiency of in vitro maturation protocols results in a final yield of mature oocytes that is similar to that obtained with cryopreserved metaphase-II oocytes.

Immature oocytes seem to be less prone to damages caused by the chilling (at the nuclear level), freezing, and thawing procedures, and they, too, can be cryopreserved by controlledrate freezing (Luvoni \& Pellizzari, 2000) or vitrification (Arav et al., 1993). Preantral oocytes can be preserved inside the follicle, and about $10 \%$ seem to be physiologically active after thawing and 1 week of culture (Nayudu et al., 2003). However, culture conditions that allow these oocytes to grow and reach full maturation are still largely unknown despite attempts in several species. The only species in which live young were produced from fresh (Eppig \& O'Brien, 1996) or frozen-thawed (Carroll et al., 1990) primary follicles is the mouse. Some very limited success was also reported in cats, where following vitrification in $40 \% \mathrm{EG}, 3.7 \%$ of the in vitro matured oocytes were able to develop to the blastocyst stage following IVF (Murakami et al., 2004). 
The problems associated with maturation of early-stage oocytes in vitro are the need to develop the complex endocrine system that supports the development at different stages, other culture conditions that will ensure survival (oxygen pressure for example) and, in many species, the duration of time required to keep the follicles in culture. Another option for isolated oocyte freezing is freezing individual primordial follicles and later transplanting them to the ovarian bursa, where they can mature and eventually produce young offspring following natural mating as was shown in mice. Alternatively, ovarian cortex tissue or the entire ovary can be frozen or vitrified and then, after thawing/warming, transplanted to allow maturation in vivo (Candy et al. 1995), or else the oocytes can be fertilized and the resulting embryos can then be cryopreserved.

\subsection{Female germplasm cryopreservation techniques}

Cryopreservation holds tissues at temperatures between $-140^{\circ}$ and $-200^{\circ} \mathrm{C}$, at which no biological activity can occur, producing a state of "suspended animation" of tissues that can be maintained indefinitely. It is the process of cooling and warming, not long-term cryostorage, that harms cells or tissue. The success of these approaches depends upon the tissue, the cryoprotectant, and the freezing vessel used.

In the intervening years, variation to oocytes cryopreservation methods including changes in sucrose and sodium concentration in slow freezing media, along with the first report of successful oocyte vitrification and the development of novel cryotools have combined to provide consistently improved survival and pregnancy rate for oocyte cryopreservation. Two basic techniques have currently been used in the field of female germplasm cryopreservation, that is, slow freezing technique (Whittingham, 1977, Whittingham et al., 1972, Wilmut, 1972, Willadsen et al., 1976; 1978) and vitrification. Slow freezing method is a standard operating procedure in most IVF centers, but it is a time consuming procedure. In the slow freezing technique germplasm is gradually exposed to relatively low concentration of permeating cryoprotectants (CPs). These are usually glycerol or DMSO in the range of 1.0-1.5 M, which are added to the culture medium. Other cryoprotectants are widely used, alone or in various combinations. These include permeating CPs such as ethylene glycol (EG) and propylene glycol (e.g. Chen, 1986) and non-permeating ones such as sucrose, glucose, or fructose. The germplasm is then loaded in small volumes into straws and cooled to $-7^{\circ} \mathrm{C}$ at -1 to $-2^{\circ} \mathrm{C} / \mathrm{min}$, seeded at $-7^{\circ} \mathrm{C}$, and further cooled to $-30^{\circ} \mathrm{C}$ to $-35^{\circ} \mathrm{C}$ at $-0.3^{\circ} \mathrm{C} / \mathrm{min}$, then free falling to $-50^{\circ} \mathrm{C}$ before plunging into liquid nitrogen. This process often takes about $3 \mathrm{~h}$. To date, there is no enough evidence to show that such slow cooling is necessary.

Another important method to improve the survivial of cryopreserved oocytes is vitrification. The vitrification is an ultra rapid freezing method and requires three important factors: high cooling rate, high viscosity of the medium and small volume. (Arav, 1992, Arav et al., 2002). Cooling rate is achieved by directly putting sample into liquid nitrogen. The sample is plunged into liquid nitrogen resulting in cooling rates of hundreds to tens of thousands degrees Celsius per min, depending on the container, the volume, the thermal conductivity, the solution composition, etc.. For enhancing the cooling rate, liquid nitrogen slush is employed instead of liquid nitrogen. Nitrogen slush can be produced from liquid nitrogen by using vacuum. To achieve liquid nitrogen slush, the liquid nitrogen needs to be cooled close to its freezing point $\left(-210^{\circ} \mathrm{C}\right)$. Slush is generated by the VitMaster (IMT Ltd, 
Ness Ziona, Israel), a device that reduces the temperature of the LN to between -205 and $-210^{\circ} \mathrm{C}$. Oocytes or embryos are suspended in the viscous medium. This is defined by the concentration and behavior of various $\mathrm{CPs}$ and other additives during vitrification. The higher the concentration of CPs, the higher the glass transition temperature (Tg), thus lowering the chance of ice nucleation and crystallization. Different CPs and other additives have different toxicity, penetration rate, and Tg. The combination of different CPs is often used to increase viscosity and $\mathrm{Tg}$, and reduce the level of toxicity. In the cattle industry, to avoid handling of the post-warmed embryos and to allow direct embryo transfer, EG is often used as the permeating CP because of its high penetration rate (Saha et al., 1996).

Recently, the less concentrated solution consisting of 15\% (v/v) EG, 15\% (v/v) DMSO or $\mathrm{PROH}$ and $0,5 \mathrm{M}$ sucrose with minimum volume can be used for human oocyte vitrification. This strategy further reduces solution toxicity. Another strategy to reduce toxic effects is the stepwise equilibration of cryoprotectants with $0.25 \mathrm{~mL}$ conventional straw. The cooling rate was around $2,500^{\circ} \mathrm{C} /$ minute and the warming rate was $1,300^{\circ} \mathrm{C} /$ minute. Using minimum volume method, a higher cooling rate can facilitate vitrification. Many techniques have been developed to reduce sample volume in the last decade. These techniques can generally be divided into two categories, surface technique and tubing technique.

The surface techniques include EM grid, minimum drop size, MDS (Arav 1992; Arav \& Zeron, 1997), Cryotop, Cryoloop, Hemi-straw, solid surface, nylon mesh, Cryoleaf, direct cover vitrification, fiber plug, vitrification spatula, Cryo-E, plastic blade, and Vitri-Inga. The tubing techniques include the plastic straw, OPS, closed pulled straw (CPS), flexipetdenuding pipette, superfine OPS, CryoTip, pipette tip, high-security vitrification device, sealed pulled straw, Cryopette, Rapid-i and JY Straw. Each of these two groups has its specific advantages. In the surface methods, small drop (less $0.1 \mathrm{ml}$ ) can achieve high cooling/warming rate because these systems are open. The tubing systems also may achieve high cooling rate in closed system and make samples untouched liquid nitrogen for safer and easier handle. Decreasing vitrified volume and increasing cooling rate allow a moderate decrease in $\mathrm{CP}$ concentration so as to minimize its toxic and osmotic hazardous effects (Barcelo-Fimbres \& Seidel, 2007). The cryotop technique has been also modified by using a hermetically sealed container for storage to eliminate potential dangers of disease transmission.

\subsection{Ovarian tissue cryopreservation}

Another source of oocytes for gamete preservation is ovarian tissue removed for ovarian tissue cryopreservation. Large follicles $1 \mathrm{~mm}$ can easily be seen on the ovarian cortex and follicles greater than $5 \mathrm{~mm}$ may be aspirated to obtain immature cumulus-oocyte complexes.

As the ovarian tissue is processed, smaller antral follicles rupture releasing oocytes that fall to the bottom of the dish ranging in size and quality from incompetent denuded oocytes to larger cumulus enclosed oocytes. Oocytes are collected from the bottom of every dish used and matured in vitro up to $40 \mathrm{~h}$. By $24 \mathrm{~h}$ in culture the cumulus granulosa, surrounding the oocyte, begins to mucify resulting in cumulus cell differentiation and expansion. By $40 \mathrm{~h}$, oocytes are stripped of cumulus cells and are examined for meiotic stage; the resulting MII oocytes are vitrified for potential future use. Although there are numerous reports about pregnancies with in vivo matured cryopreserved oocytes, only a very few of pregnancies have been obtained 
using vitrified in vitro matured oocytes and no pregnancies with slow freezing in vitro matured oocytes by ovarian tissue cryopreservation. As mentioned previously, the cortex of a normal ovary is filled with arrested, immature, primordial follicles and hundreds of primordial follicles in a $1 \mathrm{~mm}^{3}$ piece of tissue. Unlike freezing embryos and mature oocytes, the primordial follicles in cortical tissue contain small oocytes that easily survive after freezing process when the tissue is cut into small strips of $1-2 \mathrm{~mm} \times 1-2 \mathrm{~mm} \times 10 \mathrm{~mm}$.

The common ovarian tissue slow freezing protocol is as follows: after incubation in $1.5 \mathrm{M}$ ethylene glycol and $0.1 \mathrm{M}$ sucrose for $20-30 \mathrm{~min}$, cryovials with ovarian tissue pieces are cooled to $-7^{\circ} \mathrm{C}$ at $-2^{\circ} \mathrm{C} / \mathrm{min}$, seeded, and further cooled to $-40^{\circ} \mathrm{C}$ at $-0.3^{\circ} \mathrm{C} / \mathrm{min}$, then free falling to $-100^{\circ} \mathrm{C}$ before storage in liquid nitrogen. Vials are thawed in a $37^{\circ} \mathrm{C}$ water bath, and tissue pieces are washed through progressively lower concentrations of cryoprotectant media $(1.5,1.0,0.5,0)$ Methylene glycol.

Ovarian tissue transplant following tissue cryopreservation was first successfully completed in mouse and has since been successful in sheep and primates, whose ovaries more resemble those of humans. In the last few years, more than 30 cases have described the transplantation of cryopreserved or vitrified tissue to heterotopic sites such as the forearm, as well orthotopic sites such as the abdomen or back to the residual ovary. It was found, on average, that hormone ciclycity resumed within 3 and 5 months of the ovarian tissue transplant, which represents the time it takes for follicle recruitment and subsequent growth. Ovarian tissue transplantation has resulted in the birth of six children to date. As cortical tissue is isolated from the ovary, it can be cut into thin strips and cryopreserved as mentioned above; however, due to their increased oocyte size, primary and secondary follicles fail to survive the in situ freezing process. It is hypothesized that individual follicle isolation allows for better penetration of cryoprotectants, thus helping to stabilize physical connections between the follicle cells and the oocyte. Therefore, a portion of cortical tissue can be cut into smaller pieces $\left(2 \mathrm{~mm}^{3}\right)$ and treated with enzymes such as liberase or collagenase that will break down stromal tissue to aid in the release of small follicles, which then can be cryopreserved for later use. Successful slow rate cryopreservation of small secondary follicles has been shown in mice, as well as in non-human primates and humans. After thawing, individual follicles can be encapsulated into a 3D matrix such as alginate, a hydrogel made from seaweed, which supports free passage of amino acids and secreted hormones and also serves as a scaffold for follicular development. It has been shown that fresh isolated follicles from prepubescent mice are capable of follicle growth from 150 to 350 $\mu \mathrm{m}$ within 8 days of culture in alginate.

\section{Conclusion}

The widespread introduction of assisted reproductive technology over the past 20 years has seen a simultaneous increase in the development and utilization of cryopreservation technology. Cryopreservation is now considered an essential adjunction to modern reproductive treatments. It is now possible cryopreserve both gametes and embryos at a variety of different maturational stage to offer patients a significant range of options to suit their individual fertility problem. In addition to an improvement of modalities for the treatment of human infertility, the progress in cryopreservation of reproductive cells and tissues is enabling better management of livestock and laboratory animal species and better conservation of biodiversity. 
As with assisted reproduction in general, cryopreservation technology has led to the development of a number of moral and ethical issue surrounding its use. A number of these are unresolved and will continue to generate considerable debate.

\section{References}

Abe, H. \& Hoshi, H. (2003). Evaluation of bovine embryos produced in high performance serum-free media, Journal of Reproduction and Development Vol.49:193-202.

Abe, Y., Suwa, Y., Asano, T., Ueta, Y.Y., Kobayashi, N., Ohshima, N., Shirasuna, S., AbdelGhani, M.A., Oi, M., Kobayashi, Y. et al. (2011). Cryopreservation of canine embryos, Biology of Reproduction [in press].

Abir, R., Nitke, S., Ben-Haroush, A., \& Fisch, B. (2006). In vitro maturation of human primordial ovarian follicles: clinical significance, progress in mammals, and methods for growth evaluation, Histol Histopathol Vol.21(No. 8):887-898.

Aisen, E.G., Alvarez, H.L., Venturino, A. \& Garde, J.J. (2000). Effect of trehalose and EDTA on cryoprotective action of ram semen diluents, Theriogenology Vol.53:1053-1061.

Ali, J .\& Shelton, J.N. (1993). Design of vitrification solutions for the cryopreservation of embryos., J Reprod Fertil Vol. 99(No.2):471-477.

Allen, W.R. (2010). Sex, science and satisfaction: a heady brew, Animal Reproduction Science Vol. 121:262-278.

Aller, J.F., Rebuffi, G.E., Cancino, A.K. \& Alberio, R.H. (2002). Successful transfer of vitrified Ilama (Lama glama) embryos, Animal Reproduction Science Vol.73:121-127.

Almodin, C.G., Minguetti-Camara, V.C., Paixao, C.L., \& Pereira, P.C. (2010). Embryo development and gestation using fresh and vitrified oocytes, Human Reproduction Vol.25:1192-1198.

Amann, R.P. (1999) Cryopreservation of sperm, In: Knobil E, Neill JD (eds) Encyclopedia of reproduction, Academic Press, Burlington, MA, pp 773-783.

Andrabi, S., \& Maxwell, W. (2007). A review on reproductive biotechnologies for conservation of endangered mammalian species, Anim Reprod Sci Vol.99:223-243.

Arav, A. (1992). Vitrification of oocytes and embryos, In A Lauria \& F Gandolfi (eds) New Trends in Embryo Transfer,Cambridge: Portland Press, pp 255-264.

Arav, A. \& Zeron, Y. (1997). Vitrification of bovine oocytes using modified minimum drop size technique (MDS) is effected by the composition and the concentration of the vitrification solution and by the cooling conditions, Theriogenology Vol.47:341.

Arav, A., Shehu, D. \& Mattioli, M. (1993). Osmotic and cytotoxic study of vitrification of immature bovine oocytes, Journal of Reproduction and Fertility Vol.99:353-358.

Arav, A., Zeron, Y., Leslie, S.B., Behboodi, E., Anderson, G.B. \& Crowe, J.H. (1996) Phase transition temperature and chilling sensitivity of bovine oocytes. Cryobiology Vol.33:589-599.

Arav, A., Yavin, S., Zeron, Y., Natan, D., Dekel, I., \& Gacitua, H. (2002). New trends in gamete's cryopreservation, Molecular and Cellular Endocrinology Vol.187:77-81.

Armstrong, D.L., Looney, C.R., Lindsey, B.R., Gonseth, C.L., Johnson, D.L., Williams, K.R., Simmons, L.G. \& Loskutoff, N.M. (1995). Transvaginal egg retrieval and in-vitro embryo production in gaur (Bos gaurus) with establishment of interspecies pregnancy, Theriogenology Vol.43:162.

Bailey, J.L., Bilodeau, J.F. \& Cormier, N. (2000). Sperm cryopreservation in domestic animals: a damaging and capacitating phenomenon,,J Androl Vol.21:1-7. 
Barbas, J.P., \& Mascarenhas R.D. (2009). Cryopreservation of domestic animal sperm cells, Cell Tissue Bank Vol.10:49-62.

Barcelo-Fimbres, M. \& Seidel, G.E. Jr. (2007). Effects of fetal calf serum, phenazine ethosulfate and either glucose or fructose during in vitro culture of bovine embryos on embryonic development after cryopreservation, Molecular Reproduction and Development Vol.74:1395-1405.

Barrett, S.L. \&Woodruff, T.K. (2010). Gamete preservation Carcer Treat Res Vol.156:25-39.

Berg, van den L. (1959). The effect of addition of sodium and potassium chloride to the reciprocal system: $\mathrm{KH} 2, \mathrm{P} 04-\mathrm{Na} 2, \mathrm{HPO} 4-\mathrm{H} 20$ on $\mathrm{pH}$ and composition during freezing, Arch Biochem, Vol.84, 305-315.

Berg, van den, L. \& Rose, D. (1959). Effect of freezing on the $\mathrm{pH}$ and composition of sodium and potassium phosphate solutions: the reciprocal system KH2PO4-Na2, HPO4H20, Arch Biochem Vol.81, 319-329.

Bilton, R.J. \& Moore, N.W. (1976). In vitro culture, storage and transfer of goat embryos, Australian Journal of Biological Sciences Vol.29:125-129.

Breed, W.G., Taggart, D.A., Bradtke, V., Leigh, C.M., Gameau, L. \& Carroll, J. (1994). Effect of cryopreservation on development and ultrastructure of preimplantation embryos from the dasyurid marsupial Sminthopsis crassicaudata, Journal of Reproduction and Fertility Vol.100:429-438.

Bunge, R.G. \& Sherman, J.K. (1953).. Fertilizing capacity of frozen human spermatozoa, Nature Vol.172:767-768.

Candy, C.J., Wood, M.J. \& Whittingham, D.G. (1995). Follicular development in cryopreserved marmoset ovarian tissue after transplantation. Hum Reprod Vol.10(No.9):2334-2338.

Carroll, J., Depypere, H., Matthews, C.D. (1990). Freeze-thaw-induced changes of the zona pellucida explains decreased rates of fertilization in frozen-thawed mouse oocytes, J Reprod Fertil Vol.90(No.2):547-553.

Chen, C. (1986). Pregnancy after human oocyte cryopreservation, Lancet Vol.1:884-886.

Ciani, F., Cocchia, N., Rizzo, M., Ponzio, P., Tortora, G., Avallone, L. \& Lorizio, R. (2008). Sex determining of cat embryo and some feline species, Zygote, Vol.16(No.2):169-177.

Ciotti, P.M., Porcu, E., Notarangelo, L., Magrini, O., Bazzocchi, A. \& Venturoli, S. (2009). Meiotic spindle recovery is faster in vitrification of human oocytes compared to slow freezing, Fertility and Sterility Vol.91:2399-2407.

Cocchia, N., Ciani, F., El-Rass, R., Russo, M., Borzacchiello, G., Esposito, V., Montagnaro, S., Avallone, L., Tortora, G. \& Lorizio, R. (2009). Cryopreservation of feline epididymal spermatozoa from dead and alive animals and its use in assisted reproduction, Zygote Vol.18(No.1):1-8.

Cocchia, N., Ciani, F., Russo, M., El Rass, R., Rosapane, I., Avallone, L., Tortora, G. \& Lorizio, R, (2010) Immature cat oocyte vitrification in open pulled straws (OPSs) using a cryoprotectant mixture, Cryobiology Vol.60(No.2):229-34.

Comizzoli, P., Mermillod, P. \& Mauget, R. (2000). Reproductive biotechnologies for endangered mammalian specie, Reprod Nutr Dev. Vol40(No.5):493-504.

Coticchio, G., Sereni, E., Serrao, L., Mazzone, S., Iadarola, I. \& Borini, A. (2004). What criteria for the definition of oocyte quality? Annals of the New York Academy of Sciences Vol.1034:132-144. 
Cranfield, M.R., Berger, N.G., Kempske, S., Bavister, B.D., Boatman, D.E. \& Ialeggio, D.M. (1992). Macaque monkey birth following transfer of in vitro fertilized, frozenthawed embryos to a surrogate mother, Theriogenology Vol.37:197.

Donnelly, E.T., Steele, E.K., McClure, N. \& Lewis, S.E. (2001). Assessment of DNA integrity and morphology of ejaculated spermatozoa from fertile and infertile men before and after cryopreservation, Hum. Reprod. Vol.16:1191-1199.

Dresser, B.L., Gelwicks, E.J., Wachs, K.B. \& Keller, G.L. (1988). First successful transfer of cryopreserved feline (Felis catus) embryos resulting in live offspring, $J$ Exp Zool Vol.246(No.2):180-186.

Edwards, R.G., Bavister, B.D. \& Steptoe, P.C. (1969). Early Stages of Fertilization in vitro of Human Oocytes Matured in vitro, Nature Vol.221, 632-635.

Eppig, J.J., O'Brien, M., Wigglesworth, K. (1996). Mammalian oocyte growth and development in vitro, Mol Reprod Dev Vol.44(No.2):260-273.

Fabbri, R. (2006). Cryopreservation of human oocytes and ovarian tissue, Cell Tissue Bank Vol.7(No.2):113-122.

Fabbri, R., Pasquinelli, G., Braconer, G., Orrico, C., Di Tommaso, B. \& Venturoli, S. (2006). Cryopreservation of human ovarian tissue, Cell Tissue Bank Vol.7(No.2): 123-133.

Farrant, J., Walter, C., Lee, H. \& McGann, L. (1977). Use of two-step cooling procedures to examine factors influencing cell survival following freezing and thawing, Cryobiology Vol.14:273-286.

Fuller, B. \& Paynter, S. (2004). Fundamentals of cryobiology in reproductive medicine, Reprod Biomed Online Vol.9(No.6):680-691.

Fuller, B. \& Paynter, S. (2007). Cryopreservation of mammalian embryos, Methods Mol Biol Vol.368:325-339.

Gao, D.Y., Mazur, P. \& Critser, J.K. (1997). Fundamental cryobiology of mammalian spermatozoa, In: Karow AM, Critser JK (eds) Reproductive tissue banking, Academic press, San Diego pp 263-327.

Guenther, J.F., Seki, S., Kleinhans, F.W., Edashige, K., Roberts, D.M. \& Mazur, P. (2006). Extra- and intra-cellular ice formation in stage I and II Xenopus laevis oocytes, Cryobiology Vol.52:401-416.

Gupta, M.K., Uhm, S.J. \& Lee, H.T. (2010). Effect of vitrification and betamercaptoethanol on reactive oxygen species activity and in vitro development of oocytes vitrified before or after in vitro fertilization, Fertility and Sterility Vol93:2602-2607.

Herrero, L., Martinez, M. \& Garcia-Velasco, J.A. (2011). Current status of human oocyte and embryo cryopreservation, Curr Op Obstetr Gynecol Vol.23(No.4):245-250.

Holt, W.V. (1997). Alternative strategies for long-term preservation, Reprod Fertil Dev Vol.9:309-319.

Holt, W.V. (2000). Basic aspects of frozen storage semen, Anim Reprod Sci Vol.62:3-22.

Isachenko, E. (2003). Vitrification of mammalian spermatozoa in the absence of cryoprotectants: from past practical difficulties to present success, Reprod Biomed Online Vol.6(No.2):191-200.

Isachenko, E., Isachenko, V., Katkov, I.I., Rahimi, G., Schöndorf, T., Mallmann, P., Dessole, S. \& Nawroth, F. (2004a). DNA integrity and motility of human spermatozoa after standard slow freezing versus cryoprotectant-free vitrification, Hum Reprod Vol.19:932-93. 
Isachenko, V., Isachenko, E., Katkov, I.I., Montag, M., Dessole, S., Nawroth, F. \& Van Der Ven, H. (2004b). Cryoprotectant-free cryopreservation of human spermatozoa by vitrification and freezing in vapor: effect on motility, DNA integrity, and fertilization ability, Biol Reprod Vol.71:1167-1173.

Jensen, J.R., Morbeck, D.E. \& Coddington, C.C. 3rd. (2011). Fertility preservation, Mayo Clin Proc Vol.86(No.1):45-49.

Kelly, S.M., Buckett, W.M., Abdul-Jalil, A.K. \& Tan S.L. (2003). The cryobiology of assisted reproduction, Minerva Ginecol Vol.55(No.5):389-398.Krisher, R.L. (2004). The effect of oocyte quality on development, Journal of Animal Science Vol.82:E14-E23.

Krisher, R.L. (2004). The effect of oocyte quality on development, Journal of Animal Science Vol.82: E14-E23.

Kuczyński, W., Dhont, M., Grygoruk, C., Grochowski, D., Wołczyński, S. \& Szamatowicz, M. (2001) The outcome of intracytoplasmic injection of fresh and cryopreserved ejaculated spermatozoa-a prospective randomized study, Hum. Reprod. Vol.16: 2109-2113.

Kuleshova, L., Gianaroli, L., Magli, C., Ferraretti, A. \& Trounson, A. (1999). Birth following vitrification of a small number of human oocytes: case report, Hum Reprod Vol.14:3077-3079.

Kundu, C.N., Chakraborty, J., Dutta, P., Bhattacharyya, D., Ghosh, A. \&, Majumder, G.C. (2002). Effects of dextrans on cryopreservation of goat cauda epididymal spermatozoa using a chemically defined medium, Reproduction Vol.123:907-913.

Law, P., Sprott, D., Lepock, J. \& Kruuv, J. (1980) Post-thaw lysing and osmotic reactivation of frozen-thawed cell, Cryo Lett Vol.1:173-180.

Leaf, A. (1959). Maintenance of concentration gradients and regulation of cell volume, Ann. N. Y. Acad. Sci. Vol.72:396-404.

Leibo, S.P., McGrath, J.J., Cravalho, E.G. (1978). Microscopic observation of intracellular ice formation in unfertilized mouse ova as a function of cooling rate, Cryobiology Vol.15(No.3):257-71.

Liebermann, J., Nawroth, F., Isachenko, V., Isachenko, E., Rahimi, G. \& Tucker, M.J. (2002). Potential importance of vitrification in reproductive medicine, Biol Reprod Vol.67:1671-1680.

Liebermann, J., Tucker, M.J., Sills, E.S. (2003). Cryoloop vitrification in assisted reproduction: analysis of survival rates in $>1000$ human oocytes after ultra-rapid cooling with polymer augmented cryoprotectants,. Clin Exp Obstet Gynecol Vol.30:125-129.

Loskutoff, N.M., Bartels, P., Meintjes, M., Godke, R.A. \& Schiewe, M.C. (1995). Assisted reproductive technology in nondomestic ungulates: a model approach to preserving and managing genetic diversity, Theriogenology Vol.43: 3-12.

Luvoni, G.C. \& Pellizzari, P. (2000). Embryo development in vitro of cat oocytes cryopreserved at different maturation stages, Theriogenology Vol.53:1529-1540.

Lovelock, J.E. (1955). The physical instability of human red blood cells, Biochem J Vol.60(No.4):692-6.

Luvoni, G.C. (2006). Gamete cryopreservation in ther domestic cat. Theriogenology Vol.66(No.1):101-111.Luvoni, G.C. \& Pellizzari, P. (2000). Embryo development in vitro of cat oocytes cryopreserved at different maturation stages, Theriogenology Vol.53:1529-1540. 
Loskutoff, N.M., Bartels, P., Meintjes, M., Godke, R.A. \& Schiewe, M.C. (1995). Assisted reproductive technology in nondomestic ungulates: a model approach to preserving and managing genetic diversity, Theriogenology Vol.43:3-12

Lyons, J. M. (1972). Phase transitions and control of cellular metabolism at low temperatures, Crvobiology Vol.9: 341-350.

Maclellan, L.J., Carnevale, E.M., Coutinho da Silva, M.A., Scoggin, C.F., Bruemmer, J.E. \& Squires, E.L. (2002). Pregnancies from vitrified equine oocytes collected from superstimulated and non-stimulated mares,. TheriogenologyVol. 58(No.5):911-919.

Mavrides, A. \& Morroll, D. (2005). Bypassing the effect of zona pellucida changes on embryo formation following cryopreservation of bovine oocytes, Eur J Obstet Gynecol Reprod Biol Vol.118(No.1):66-70.

Mazur, P. (1963). Kinetics of water loss from cells at subzero temperatures and the likelihood of intracellular freezing J Gen Physiol. Vol.47:347-369.

Mazur, P. (1977). Slow-freezing injury in mammalian cells, Ciba Found Symp Vol.52:19-48.

Mazur, P., Leibo, S.P. \& Chu, E.H.Y. (1972). A two factor hypothesis of freezing injury, Exp Cell Res Vol.71:345-355.

Mazur, P. \& Schmidt, J. (1968). Interactions of cooling velocity, temperature, and warming velocity on the survival of frozen and thawed yeast, Cryobiology Vol.5:1-17.

Mazur, P. \& Schneider, U. (1986). Osmotic responses of preimplantation mouse and bovine embryos and their cryobiological implication, Cell Biophys Vol.8:259-285.

McGann, L. \& Farrant J. (1976). Survival of tissue culture cells frozen by a two-step procedure to $-196^{\circ} \mathrm{C}$. II. Warming rate and concentration of dimethylsulfoxide, Cryobiology Vol.13:269-273.

Medeiros, C.M., Forell, F., Oliveira, A.T. \& Rodriguez, J.L. (2002). Current status of sperm cryopreservation: why isn't better? Theriogenology Vol.57:327-344.

Meistrich, M.L., Wilson, G., Ye, W.S., Thrash, C. \& Huhtaniemi, I. (1996). Relationship among hormonal treatments, suppression of spermatogenesis, and testicular protection from chemotherapy-induced damage, Endocrinology Vol.137: 3823-3831.

Moor, R.M., Dai, Y., Lee, C., Fulka, J. Jr. (1998). Oocyte maturation and embryonic failure, Human Reproduction Update Vol.4:223-226.

Morris, G.J., Acton, E, \& Avery, A. (1999).A novel approach to sperm cryopreservation, Hum Reprod Vol.14:1013-1021.

Muldrew, K. \& McGann, L.E. (1990). Mechanisms of intracellular ice formation, Biophys J Biophysical Society Vol.57:525-532.

Mullen, S.F. \& Critser, J.K. (2007). The science of cryobiology, in Woodruff T.K. \& Snyder K.A. (eds) Oncofertility: fertility preservation for cancer survivors, New York: Springer pp. 83-103.

Murakami, M., Otoi, T., Karja, N.W., Wongsrikeao, P., Agung, B. \& Suzuki, T. (2004). Blastocysts derived from in vitro-fertilized cat oocytes after vitrification and dilution with sucrose, Cryobiology Vol-48:341-348.

Nayudu, P., Wu, J. \& Michelmann, H. (2003). In vitro development of marmoset monkey oocytes by pre-antral follicle culture, Reproduction in Domestic Animals Vol.38:90-96.

Nawroth, F., Rahimi, G., Isachenko, E., Isachenko, V., Lieberman, M., Tucker, M.J. \& Lieberman, J. (2005). Cryopreservation I Assisted Reproductive Technology: New Trends, Seminars Reprod Med Vol.23(No.4):325-335. 
Noyes, N., Boldt, J. \& Nagy, Z.P. (2010). Oocyte cryopreservation: is it time to remove its experimental label? Journal of Assisted Reproduction and Genetics Vol.27:69-74.

Palermo, G., Devroey, P., Van Steirteghem, A.C. \& Joris, H. (1992). Pregnancies after intracytoplasmic injection of single spermatozoon into an oocyte, Lancet Vol.340:17-18.

Pegg, D. (1976). Long-term preservation of cells and tissues: a review, J cli. Path Vol.29: 271-285.

Pegg, D.E. (2007). Principles of cryopreservation, Methods Mol Biol Vol.368:39-57.

Polge, C., Smith, A.Y. \& Parkes, A.S. (1949). Revival of spermatozoa after vitrification and dehydration at low temperature, Nature Vol.164:666.

Pope, C.E. (2000). Embryo technology in conservation efforts for endangered felids, Theriogenology Vol.53:163-174.

Pope, C.E., Pope, V.Z. \& Beck, L.R. (1984). Live birth following cryopreservation and transfer of a baboon embryo, Fertility and Sterility Vol.42:143-145.

Ptak, G., Clinton, M., Barboni, B., Muzzeddu, M., Cappai, P., Tischner, M. \& Loi, P. (2002). Preservation of the wild European mouflon: the first example of genetic management using a complete program of reproductive biotechnologies Biology of Reproduction Vol.66:796-801.

Purdy, P.H. (2006). A review on goat sperm cryopreservation, Small Rum Res Vol.6:215-225.

Rall, W.F. \& Fahy, G.M. (1985). Ice-free cryopreservation of mouse embryos at $-196^{\circ} \mathrm{C}$ by vitrification, Nature Vol.313:573-575.

Roth, T.L., Armstrong, D.L., Barrie, M.T. \& Wildt, D.E. (1997). Seasonal effects on ovarian responsiveness to exogenous gonadotrophins and successful artificial insemination in the snow leopard (Uncia uncia) Reprod Fertil Dev Vol.9(No.3):285-295.

Ruffing, N.A., Steponkus, P.L., Pitt, R.E. \& Parks, J.E. (1993):.Osmometric behavior, hydraulic conductivity, and incidence of intracellular ice formation in bovine oocytes at different developmental stages, Cryobiology Vol.30(No.6):562-80.

Saha, S., Otoi, T., Takagi, M., Boediono, A., Sumantri, C. \& Suzuki, T. (1996). Normal calves obtained after direct transfer of vitrified bovine embryos using ethylene glycol, trehalose, and polyvinylpyrrolidone, Cryobiology Vol.33:291-299.

Salamon, S. \& Maxwell, W.M. (2006). Storage of ram semen, Anim Reprod Sci Vol.62:77-111.

Saragusty, J.J. \& Arav, A. (2011). Current progress in oocyte and embryo cryopreservation by slow freezing and vitrification, Reproduction Vol141:1-19.

Siimes, M.A. \& Rautonen, J. (1990). Small testicles with impaired production of sperm in adult male survivors of childhood malignancies, Cancer Vol.65:1303-1306.

Shaw, J.M. (2000). Cryopreservation of oocytes and embryos. In Trounson AO; Gardner DK (eds) Handbook of in vitro fertilization. 2. Boca Raton: CRC Press LLC, p.373-368.

Sherman, J.K. (1964). Low temperature research on spermatozoa and eggs, Cryobiology Vol.1(No.2): 103-129.

Sherman, JK (1973). Synopsis of the use of frozen human semen since 1964: state of the art of human semen banking, Fertil. Steril. Vol.24:397-412.

Song, Y., Sharp, R., Lu, F. \& Hassan, M. (2010). The future potential of cryopreservation for assisted reproduction, Cryobiology Vol.60:S60-S65.

Takagi, M., Kim, I.H., Izadyar, F., Hyttel, P., Bevers, M.M., Dieleman, S.J., Hendriksen, P.J. \& Vos. P.L. (2001). Impaired final follicular maturation in heifers after superovulation with recombinant human FSH, Reproduction Vol.121:941-951. 
Thomson, B., Campbell, A.J., Irvine, D.C., Anderson, A.R., Kelnar, C.J. \& Wallace, W.H. (2002). Semen quality and spermatozoal DNA integrity in survivors of childwood cancer: a case-control study, Lancet Vol.360:361-367.

Thurston, L.M., Siggins, A., Mileham, P.F., Watson, P.F. \& Holt, W.V. (2002). Identification of amplified restriction fragment length polymorphism markers linked to genes controlling boar sperm viability following cryopreservation, Biol Reprod Vol.66:545554.

Vajta, G. \& Nagy, Z.P. (2006). Are programmable freezers still needed in the embryo laboratory? Review on vitrificatio, Reprod Biomed Online Vol.12:779-96.

Whittingham, D.G. (1977). Fertilization in vitro and development to term of unfertilized mouse oocytes previously stored at K196 8C, Journal of Reproduction and Fertility Vol.49:89-94.

Whittingham, D.G. \& Adams, C.E. (1974). Low temperature preservation of rabbit embryos, Cryobiology Vol.11:560-561.

Whittingham, D.G., Leibo, S.P. \& Mazur, P. (1972). Survival of mouse embryos frozen to K196 8C and K269 8C, Science Vol.178 411-414.

Willadsen, S.M., Polge, C., Rowson, L.E.A. \& Moor, R.M. (1974). Preservation of sheep embryos in liquid nitrogen, Cryobiology Vol11:560.

Willadsen, S.M., Polge, C., Rowson, L.E.A. \& Moor, R.M.. (1976). Deep freezing of sheep embryos, Journal of Reproduction and Fertility Vol.46:151-154.

Willadsen, S., Polge, C. \& Rowson, L.E.A. (1978). The viability of deep-frozen cow embryos. Journal of Reproduction and Fertility Vol.52:391-393.

Wilmut, I. (1972). The effect of cooling rate, warming rate, cryoprotective agent and stage of development of survival of mouse embryos during freezing and thawing, Life Sciences Vol.11:1071-1079.

Wilmut, I. \& Rowson, L.E. (1973). Experiments on the low-temperature preservation of cow embryos, Veterinary Record Vol.92:686-690.

Wolf, D.P., Vandevoort, C.A., Meyer-Haas, G.R., Zelinski-Wooten, M.B., Hess, D.L., Baughman, W.L. \& Stouffer, R.L. (1989). In vitro fertilization and embryo transfer in the rhesus monkey, Biology of Reproduction Vol.41:335-346.

Woods, E.J., Benson, J.D., Agca, Y. \& Crister, J.K. (2004). Fundamental cryobiology of reproductive cells and tissue, Cryobiology Vol.48:146-156. 


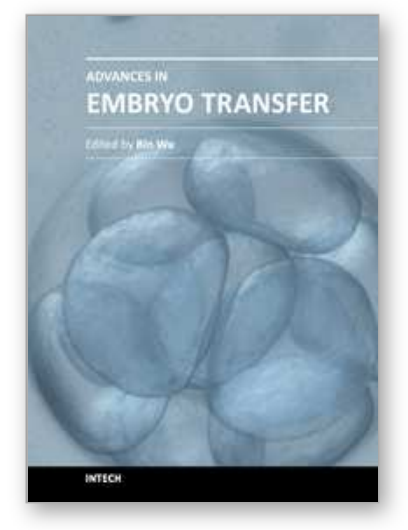

\author{
Advances in Embryo Transfer \\ Edited by Dr. Bin Wu
}

ISBN 978-953-51-0318-9

Hard cover, 248 pages

Publisher InTech

Published online 14, March, 2012

Published in print edition March, 2012

Embryo transfer has become one of the prominent high businesses worldwide. This book updates and reviews some new developed theories and technologies in the human embryo transfer and mainly focus on discussing some encountered problems during embryo transfer, which gives some examples how to improve pregnancy rate by innovated techniques so that readers, especially embryologists and physicians for human IVF programs, may acquire some new and usable information as well as some key practice techniques. Major contents include the optimal stimulation scheme for ovaries, advance in insemination technology, improved embryo transfer technology and endometrial receptivity and embryo implantation mechanism. Thus, this book will greatly add new information for readers to improve human embryo transfer pregnancy rate.

\title{
How to reference
}

In order to correctly reference this scholarly work, feel free to copy and paste the following:

Francesca Ciani, Natascia Cocchia, Luigi Esposito and Luigi Avallone (2012). Fertility Cryopreservation, Advances in Embryo Transfer, Dr. Bin Wu (Ed.), ISBN: 978-953-51-0318-9, InTech, Available from: http://www.intechopen.com/books/advances-in-embryo-transfer/fertility-cryopreservation

\section{INTECH}

open science | open minds

\section{InTech Europe}

University Campus STeP Ri Slavka Krautzeka 83/A 51000 Rijeka, Croatia Phone: +385 (51) 770447

Fax: +385 (51) 686166 www.intechopen.com

\section{InTech China}

Unit 405, Office Block, Hotel Equatorial Shanghai No.65, Yan An Road (West), Shanghai, 200040, China 中国上海市延安西路65号上海国际贵都大饭店办公楼 405 单元 Phone: +86-21-62489820

Fax: $+86-21-62489821$ 
(C) 2012 The Author(s). Licensee IntechOpen. This is an open access article distributed under the terms of the Creative Commons Attribution 3.0 License, which permits unrestricted use, distribution, and reproduction in any medium, provided the original work is properly cited. 